CASE NOTE

\title{
JUDGMENT NO 335-13-JP (12 AUGUST 2020) (CONSTITUTIONAL COURT OF ECUADOR)
}

\author{
ANA MARÍA MORENO-SÁCHICA*
}

TABLE OF CONTENTS

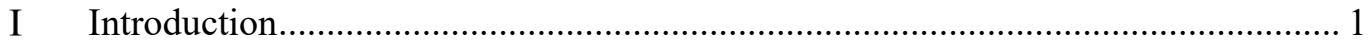

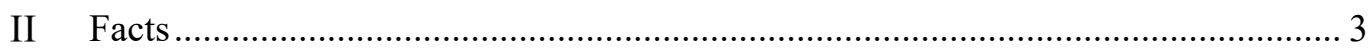

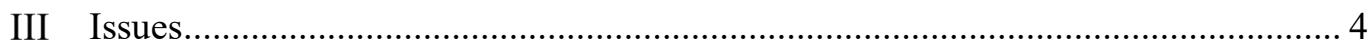

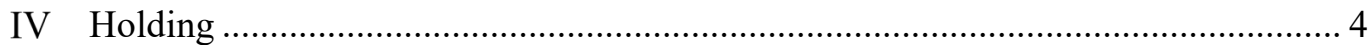

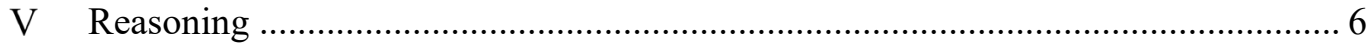

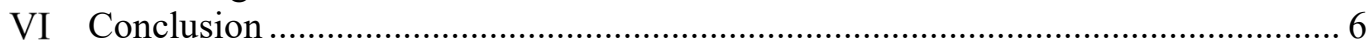

\section{INTRODUCTION}

Ecuador is a party to the main international human rights instruments, such as the universal and Inter-American protection systems, including the American Convention on Human Rights ('ACHR'), the International Covenant on Civil and Political Rights, the International Convention on the Protection of the Rights of All Migrant Workers and Members of Their Families ('CRMW'), the Convention Relating to the Status of Stateless Persons and the Convention on the Reduction of Statelessness. ${ }^{1}$ In addition, Ecuador recently achieved important constitutional and legislative developments in respect of the rights of migrants. For example, several provisions contained in the Constitution of the Republic of Ecuador 2008 ('Constitution of Ecuador') ${ }^{2}$ and in the Organic Law on Human Mobility 2017,, along with its regulations and latest reform contained in the Organic Law Reforming the Organic Law on Human Mobility of 5 February 2021,4 seek to protect and guarantee the rights of migrants, immigrants, persons in transit, persons with international protection needs, victims of human trafficking crimes and the illegal smuggling of migrants.

* Ana María Moreno-Sáchica is a Legal Affairs Adviser of the Border Management Unit at the Presidency of the Republic of Colombia.

1 American Convention on Human Rights, opened for signature 22 November 1969, 1144 UNTS 123 (entered into force 18 July 1978) ('ACHR'); International Covenant on Civil and Political Rights, opened for signature 16 December 1966, 999 UNTS 171 (entered into force 23 March 1976); International Convention on the Protection of the Rights of All Migrant Workers and Members of Their Families, opened for signature 18 December 1990, 2220 UNTS 3 (entered into force 1 July 2003) (' $C R M W$ '); Convention Relating to the Status of Stateless Persons, opened for signature 28 September 1954, 360 UNTS 117 (entered into force 6 June 1960); Convention on the Reduction of Statelessness, opened for signature 30 August 1961, 989 UNTS 175 (entered into force 13 December 1975).

2 Constitution of the Republic of Ecuador 2008, arts 6, 40-41 ('Constitution of Ecuador').

3 Organic Law on Human Mobility (2017) 938 Official Registry Supplement 1 (Ecuador).

4 Organic Law Reforming the Organic Law on Human Mobility (2021) II(386) Official Registry 2 (Ecuador). 
Within this context, the Ecuadorian constitutional ruling Judgment No 335-13$J P 20$ of 12 August 2020 (' $J P$ ') is the first case that addresses deprivation of Ecuadorian nationality. ${ }^{5}$ This case concerned a Cuban citizen, the plaintiff, who obtained Ecuadorian nationality by naturalisation and the subsequent withdrawal of that nationality. Due to an improper notification of the decision to withdraw said nationality, the plaintiff was not afforded the minimum guarantees offered by due process. As a consequence, the plaintiff was detained, illegally and arbitrarily, for more than three days at Guayaquil Airport, returned from his country of origin and deprived of his Ecuadorian identification documents. ${ }^{6}$

The plaintiff brought an 'action of protection'7 for the recognition of his rights, which was denied in the first and second instances, and subsequently reviewed by the Constitutional Court of Ecuador. ${ }^{8}$ The Constitutional Court overturned the previous judicial decisions, recognised the violation of the plaintiff's rights and ordered economic reparation as compensation for the damages caused. ${ }^{9}$

The plaintiff's case is one of several cases concerning naturalised foreigners who were notified of the decision to revoke their nationality through a press bulletin, without the possibility of presenting their case. This caused a denial of access to justice, aggravated by leaving the persons concerned in an irregular migratory situation.

At the time of the facts, this case and those of other foreigners in similar circumstances had been denied by judges of first and second instances. This was based on the argument that, because they were administrative decisions, they should be heard by the administrative courts. ${ }^{10}$ However, this meant there was no possibility of obtaining a prompt solution and the reestablishment of the violated rights.

This type of administrative and judicial action had not been subject to review by the Constitutional Court of Ecuador until now. This decision is a milestone for the Ecuadorian jurisprudence and legal system in relation to the right to due process in administrative actions, especially those related to the right to nationality, the right to liberty and personal integrity in the case of arbitrary and illegal detentions, and the right to migrate, as set out in the Constitution of Ecuador. ${ }^{11}$

Undoubtedly, the decision adopted by the Constitutional Court of Ecuador in $J P$ sets a precedent, which in turn will have repercussions at the legislative level in terms of guaranteeing the right to nationality and the prohibition of arbitrary deprivation of nationality, in a regional context where there are not many developments in the jurisprudence of national courts on nationality, statelessness and due process. It also establishes a framework of minimum guarantees and standards in cases of revocation of nationality, thereby limiting the discretionary

5 Judgment No 335-13-JP (12 August 2020) (Constitutional Court of Ecuador) (' $J P$ ').

6 ibid 5 [29]-[31] (Salazar Marín J).

7 The 'action of protection' is a jurisdictional action of the Ecuadorian legal system for the protection of human rights, similar to the 'Recurso de Amparo' in Mexico and Spain. This action is provided for in the Constitution of Ecuador (n 2) art 88 and can be filed when there is a violation of constitutional rights, by the action or omission of a non-judicial public authority.

8 See JP (n 5), 6 [35]-[36]; Action of Protection No 09123-2013-0171 (Third Criminal and Traffic Chamber, 15 April 2013) (Provincial Court) (Ecuador) ('Action of Protection No 09123-2013-0171'), cited in $J P$ (n 5) 1 [1].

$9 \quad J P($ n 5) 29 [142], 31-2 [149]-[150] (Salazar Marín J).

$10 J P$ (n 5) 6 [35], citing Action of Protection No 09123-2013-0171 (n 8).

11 Constitution of Ecuador (n 2) arts 6, 40, 77. 
power of the state, based on the basic norms and principles of the inter-American human rights system.

\section{FACTS}

The plaintiff, who is of Cuban nationality, applied for Ecuadorian nationality by naturalisation, due to a common-law marriage to an Ecuadorian citizen. In 2009, the Ministry of Foreign Affairs and Human Mobility, ('the Ministry') granted him Ecuadorian nationality by naturalisation. ${ }^{12}$ In mid-2010, the Ministry revoked the plaintiff's nationality, suspended his rights by virtue of nationality and ordered the deactivation and withdrawal of his Ecuadorian identification documents. The Ministry based its decision on the fact that the plaintiff provided a false document and therefore did not comply with one of the requirements under Ecuadorian law for the acquisition of nationality. ${ }^{13}$

The Ministry published a press release with the names of the persons whose nationality had been revoked by naturalisation, without individualising the content of the acts of revocation. ${ }^{14}$ Similarly, in the Court's file, there is no record of notification to the plaintiff of the decision revoking the nationality. Despite there being no record of the notification, in 2013, the Contentious Administrative District Court of Quito declared the decision to revoke the plaintiff's nationality to be in accordance with the law. ${ }^{15}$ In this regard, it should be clarified that within the framework of the Ecuadorian judicial system, there is the contentiousadministrative jurisdiction in charge of the control of the legality of administrative acts issued by the public administration. On the other hand, there is the constitutional jurisdiction, which is responsible for the review of the decisions of the judges of instance in the action of protection claim relating to human rights.

In 2011, the plaintiff had his Ecuadorian identification documents withheld upon his departure to Cuba through Guayaquil Airport. He was subsequently detained in the same place for more than three days and returned by the migration authorities of Cuba. ${ }^{16}$ In 2013, the plaintiff filed an action for protection against the Ministry and other entities, in which he alleged that he was not notified of the resolution that revoked his nationality, which was denied in the first instance, appealed by the plaintiff, and confirmed in the second instance. ${ }^{17}$

The first instance judges agreed that this action was not the appropriate mechanism to define the legality of the act of revocation of nationality, that there had been no violation of the rights alleged by the plaintiff, and that there were no other means of legal defence to challenge the act of revocation. ${ }^{18}$ Finally, the second instance judgment was referred to the Constitutional Court of Ecuador for review. ${ }^{19}$ The Court then issued the $J P$ decision.

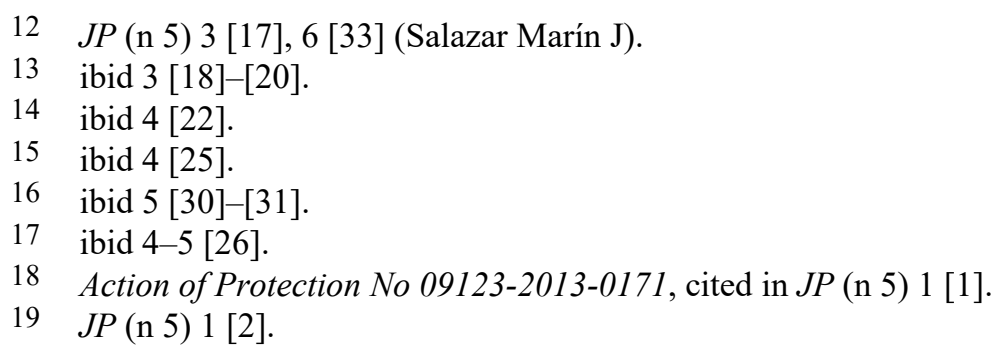




\section{ISSUES}

The legal issues that were raised by the Constitutional Court of Ecuador were the following:

1. The act of revocation of the Ecuadorian nationality granted by naturalisation to the plaintiff:

1.1 Did it violate his right to due process?

1.2 Did it violate his right to nationality?

2. The detention alleged by the plaintiff at Guayaquil Airport:

2.1 Did it violate his rights to liberty and personal integrity?

2.2 Was it a violation of his right to migrate? ${ }^{20}$

\section{HOLDING}

On the violation of the right to due process, the Court established that the minimum guarantees of due process must be applied in any administrative proceeding, especially if a person's right to nationality is at stake. ${ }^{21}$

The minimum standards of due process of law that should govern administrative proceedings were identified by both the Inter-American Commission on Human Rights and the Inter-American Court of Human Rights ('IACrtHR'). ${ }^{22}$ In this case, the Court determined that they were ignored, due to the failure to notify of the initiation of the proceedings and of the administrative act of revocation of nationality, in which the reasons for this decision were explained. ${ }^{23}$

Consequently, the plaintiff was unable to exercise his right of defence, present evidence or lodge appeals against the revocation decision, which violated the right to due process in art 76 of the Constitution of Ecuador and resulted in the deprivation of nationality being arbitrary. ${ }^{24}$ This is based on the Inter-American Principles on the Human Rights of All Migrants, Refugees, Stateless Persons and Victims of Human Trafficking which refer to the deprivation of nationality as follows: 25

States may not withdraw nationality except in very limited circumstances, based on non-discriminatory reasons under law, with full due process including notice and opportunity to challenge the decision.

Migrants shall not be arbitrarily deprived of their nationality $[\ldots]^{26}$

Similarly, in relation to the revocation of nationality, the Court established that the decision must take place in individualised and 'non-massive procedures', through a prior and personal notification which allows the person to appear and

$20 J P($ n 5) 7 [41] (Salazar Marín J).

21 ibid 7 [39].

22 Inter-American Commission on Human Rights, Human Rights of Migrants, Refugees, Stateless Persons, Victims of Human Trafficking and Internally Displaced Persons: Norms and Standards of the Inter-American Human Rights System, OEA/Ser.L/V/II.Doc46/15 (31 December 2015).

$23 J P($ n 5) 10-11 [55]-[56].

24 Constitution of Ecuador (n 2) art 76.

25 Inter-American Commission on Human Rights, Inter-American Principles on the Human Rights of All Migrants, Refugees, Stateless Persons and Victims of Human Trafficking, Resolution 04/19 (7 December 2019).

26 ibid 11, Principle 25 (emphasis added). 
oppose the procedure. ${ }^{27}$ The use of press notification should be an ultima ratio measure. ${ }^{28}$

On the other hand, in relation to the second question of law, on whether the revocation of nationality by naturalisation violated the plaintiff's right to nationality, the Court based its reasoning on the $A C H R$ and found that the deprivation of his right to nationality was arbitrary. ${ }^{29}$ This was due to the absence of an assessment of the effects of the revocation decision and the possible needs for international protection in the plaintiff's particular case. ${ }^{30}$

Likewise, the Court recognised the discretionary power of the state to determine the grounds for revocation of nationality by naturalisation, as long as this power is not used for arbitrary acts and that the human rights of all persons under its jurisdiction are guaranteed in all procedures with a direct impact on the right to nationality and, indirectly, on the enjoyment of other rights. ${ }^{31}$

Thus, according to the Constitutional Court, any procedure related to the person's right to nationality must consider the effects of the decision adopted, to avoid statelessness or irregular immigration statuses. ${ }^{32}$

The Court determined that any authority adopting a decision affecting the right to nationality must analyse situations of statelessness through particular international obligations. First those derived from human rights and statelessness instruments. Second, the IACrtHR's findings on the obligation of states to prevent, avoid and reduce statelessness in regulating nationality and recognising the need for international protection for those without a nationality. ${ }^{33} \mathrm{In} J P$, it is noted that the plaintiff lost his Cuban nationality by acquiring Ecuadorian nationality through naturalisation, in accordance with the legislation on the acquisition of Cuban nationality. ${ }^{34}$ The Ministry did not notice this when issuing the administrative act, which revoked the plaintiff's Ecuadorian nationality. 35

The Court also held that it is necessary to assess the immigration status of the person whose nationality was revoked, to inform them of the alternatives available to regularise their status and avoid situations of irregularity. ${ }^{36}$

All of the foregoing led the Constitutional Court to conclude that there was a violation of the right to nationality provided for in art 6 of the Constitution of Ecuador, due to arbitrary deprivation of the plaintiff's right to nationality. ${ }^{37}$

The Court determined that the detention of the plaintiff at Guayaquil Airport constituted a violation of his rights to liberty and personal integrity. It was arbitrary as the plaintiff was detained for more than three days without a court order, legal process or supervision by a jurisdictional authority, in accordance with the Court's jurisprudence on the matter. ${ }^{38}$ The inhuman conditions to which the plaintiff was

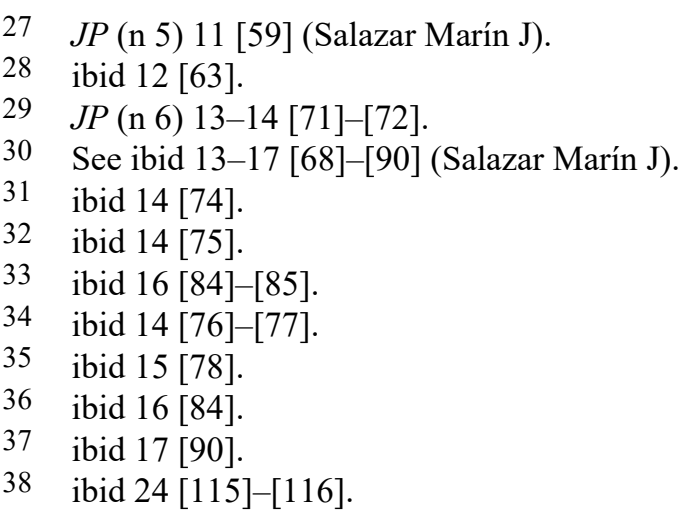


subjected violated these rights, which are provided for in arts 77 and 66 of the Constitution of Ecuador. ${ }^{39}$

Finally, the Court ruled that the arbitrary detention of the plaintiff disregarded his right to migrate, considering that 'detentions of persons based on their migratory status, regardless of the place of detention, whether in airports, transit zones or "international" zones, are practices that promote the criminalisation of migration', ${ }^{40}$ under art 40 of the Constitution of Ecuador, art 16 of the CRMW ${ }^{41}$ and art 7 of the $A C H R .{ }^{42}$

\section{REASONING}

The ruling handed down by the Constitutional Court of Ecuador in $J P$ has no precedent in the Ecuadorian legal system. It also has no precedent in the domestic legal systems of the region in terms of the right to nationality, statelessness, limits of the discretionary power of the state in cases of revocation of nationality by naturalisation and minimum guarantees of due process to avoid arbitrary deprivation of nationality.

In addition, the Constitutional Court established clear guidelines on the following issues:

(a) Characteristics of the notification of decisions in proceedings for revocation of nationality or with revocation effects. ${ }^{43}$

(b) Limits to the detention of migrants in transit or in international zones at airports, in accordance with the duration of detention, as a guarantee to avoid arbitrariness. ${ }^{44}$

(c) Adequacy of the mechanism of the action for protection for the defence of the constitutional rights of persons in a situation of human mobility. ${ }^{45}$

Each of the parameters indicated by the Constitutional Court of Ecuador is based on the human rights norms and principles of the Inter-American system. The judgment supports, through jurisprudence, compliance with the standards of protection being binding on the countries of the region. It is clear from the characteristics of the judgment that it is binding as a constitutional precedent, with erga omnes effects established by the Court itself in future analogous cases.

\section{CONCLUSION}

Although the Constitutional Court of Ecuador has made other pronouncements related to the right to nationality in cases of birth registration of children of samesex couples, ${ }^{46}$ or persons recognised as refugees, ${ }^{47}$ the ruling discussed is a unique decision and without any precedent concerning the issues addressed.

As such, it is likely to have an important impact on the Ecuadorian legal system for future judicial and regulatory developments. In particular, the regulations that the Executive is advancing in the recently issued Organic Law Reforming the

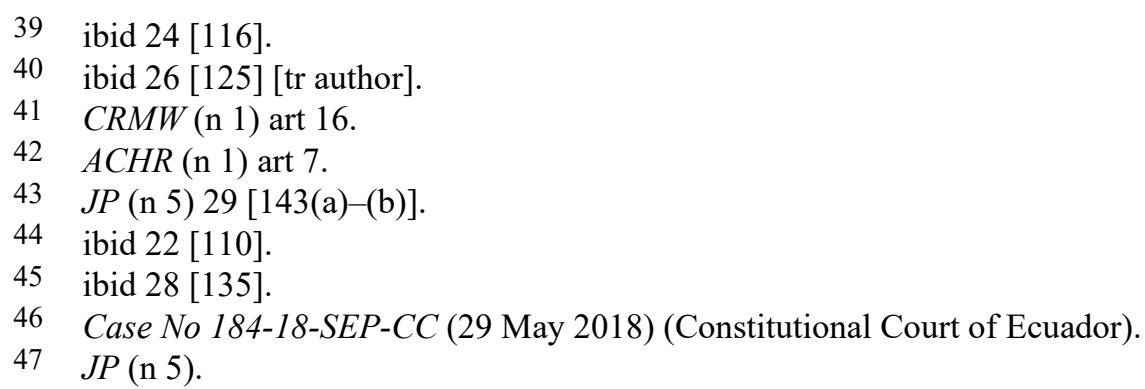


Organic Law on Human Mobility will surely take into account the criteria established by the Court regarding the guarantee of the right to nationality in connection with the right to due process, in all administrative procedures and actions which can affect a person's nationality. ${ }^{48}$

Similarly, $J P$ will serve as a reference for other constitutional courts in the region, where jurisprudence on the right to nationality and statelessness is still incipient.

48 Organic Law Reforming the Organic Law on Human Mobility (n 4). 